\title{
Impact of Composts Maturity on Growth and Agronomic Parameters of Maize (Zea mays)
}

\author{
Mawuli Tamakloe1, Edem Komi Koledzi1 ${ }^{*}$, Etsè Aziable1, Maglwa Tcha-Thom¹, \\ Nitale M'Balikine Krou²
}

${ }^{1}$ Laboratory of Waste Management, Treatment and Recovery (Laboratory GTVD), Faculty of Sciences, University of Lomé, Lomé, Togo

${ }^{2}$ Laboratory of Sanitation, Water Science and Environment (LSEE), Faculty of Science and Technology, University of Kara, Kara, Togo

Email: *edemledzi@yahoo.fr

How to cite this paper: Tamakloe, M., Koledzi, E.K., Aziable, E., Tcha-Thom, M. and Krou, N.M. (2021) Impact of Composts Maturity on Growth and Agronomic Parameters of Maize (Zea mays). American Journal of Analytical Chemistry, 12 , $29-45$.

https://doi.org/10.4236/ajac.2020.122003

Received: December 14, 2020

Accepted: February 22, 2021

Published: February 25, 2021

Copyright $\odot 2021$ by author(s) and Scientific Research Publishing Inc. This work is licensed under the Creative Commons Attribution International License (CC BY 4.0).

http://creativecommons.org/licenses/by/4.0/

\begin{abstract}
Several methods have been developed in the literature which allow the maturity of composts to be assessed before it is used in agriculture. The objective of this study is to assess the maturity of the composts produced at the platform of the NGO ENPRO in Lomé on the growth and agronomic parameters of maize (Zea mays L., var. IKENE). To do so, three types of compost (gargabe, fruit waste, animal litter) were made for at least 3 months. The chemical analysis, phytotoxicity and agronomic tests carried out made it possible to assess the maturity of these composts. Indeed, the evolution of the $\mathrm{C} / \mathrm{N}$ ratio, of the electrical conductivity, the phytotoxicity tests and the growth parameters of the composts show that the composts $\mathrm{N}^{\circ} 1$ and $\mathrm{N}^{\circ} 2$ are mature at the end of the $3^{\text {rd }}$ month of composting while the compost $\mathrm{N}^{\circ} 3$ can only be considered mature at the end of the $5^{\text {th }}$ month of composting. But, with a yield of $2.39 \pm 0.28 \mathrm{t} / \mathrm{ha}$ and a mass of 1000 grains of $346 \pm 4 \mathrm{~g}$, the treatment at $5 \mathrm{t} / \mathrm{ha}$ of compost $\mathrm{N}^{\circ} 3$, has the best agronomic parameters compared to other types of compost and treatment without organic amendment. These results also show that compost with a high electrical conductivity has an inhibitory effect on the growth of corn plants (Zea mays L., var. IKENE). Basic chemical analysis, phytotoxicity tests and height growth of maize (Zea mays L., var. IKENE) are relatively efficient methods for evaluating the maturity of composts.
\end{abstract}

\section{Keywords}

Compost, Phytotoxicity, Agronomic Parameters, Growth, Maize (Zea mays L., var. IKENE) 


\section{Introduction}

The accelerated growth of the population in developing countries generates an increase of the food demand [1]. To satisfy this demand, agricultural intensification appears as an unavoidable option which is putting pressure on the ecosystem and in turn leading to reduced soil fertility. Togo, like the other countries of sub-Saharan Africa, is faced with a decline in soil fertility which leads to increasingly low yields and therefore very far from potential crop yields. Agricultural production is still largely cereals on soils that are not very productive and naturally poor in mineral elements essential for germination and growth and good crop yields. Akanza and Yao-Kouamé (2011) find that the nutrients exported from the already poor soil by crop harvests are not sufficiently well replaced and the use of mineral or organic fertilizers in food crops remains insignificant [2]. The use of chemical fertilizers by Togolese farmers has also shown its limits. To reverse the trend, the rational supply of organic fertilizers, composts, is now necessary to support the soils and improve the yields of all crops, in particular that of maize, which is Togo's main food crop. Despite a high potential yield, maize cultivation is characterized by low productivity. This low crop productivity is believed to be due to several constraints, mainly inappropriate soil fertilization practices [3]. Compost clearly appears as an organic amendment that can allow maize to achieve its genetic potential in a sustainable way. Indeed, compared to the original substrates, composts, among other advantages, have a beneficial effect on the growth of plants, improve the structure of soils by increasing aggregates and also improve the physical and chemical qualities of soils by providing nutrients that are progressively assimilable for plants [4]. Rational use of composts involves controlling the substrates used, managing the composting process and especially the degree of maturation. Indeed, it is generally accepted that compost produced with substrates rich in nitrogen will have a better fertilizing effect, compared to other compost whose substrates are mainly woody. Likewise, immature compost will have a repressive effect on seed germination and plant growth [5]. Compost with high salinity and containing toxic elements also has a repressive effect on plant growth. To assess the maturity of compost, several parameters are used by different authors. Some authors associate maturity with the $\mathrm{C} / \mathrm{N}$ ratio, between 15 and 20 (AFNOR standard, reported by [6]). Others believe that this $\mathrm{C} / \mathrm{N}$ ratio is far from sufficient. It should be combined with $\mathrm{pH}$, organic matter content and phytotoxicity tests [7]. The main objective of this study is to assess the maturity of three types of composts, at different composting times through the study of chemical characteristics, nutrients, phytotoxicity tests and agronomic tests on corn (Zea mays L., var. IKENE).

\section{Materials and Methods}

\subsection{Nature of Waste and Waste Composting Process}

After a pre-collection by voluntary contribution from the populations and a door-to-door pre-collection mainly provided by neighborhood associations us- 
ing human-drawn carts and motorized carts [8], the waste from the Djidjolé neighborhoods, Agbalepedogan and Adidogomé are transported directly to the composting platform of the NGO ENPRO in Lomé. Three types of compost (Table 1) have been developed from waste: compost $\mathrm{N}^{\circ} 1$ made up of household waste, compost $\mathrm{N}^{\circ} 2$ made up of $50 \%$ pineapple waste and $50 \%$ household garbage, compost $\mathrm{N}^{\circ} 3$ made up of animal litter and straw. Each type of compost is duplicated.

The windrow composting method is the one chosen for this study because it is the method used on the platform. $600 \mathrm{~kg}$ of waste are used for each type of compost and placed in piles (windrows) alternately in three series of layers. According to Puyuelo et al. (2010) [9], the minimum oxygen level in the gaps in a fermentation windrow should be $5 \%$. Conditions favorable to anaerobiosis occur if the oxygen content is too low or the mass to be composted too compact. To guarantee a grade above this value, reversals were made on the $3^{\text {rd }}, 10^{\text {th }}, 22^{\text {nd }}, 36^{\text {th }}$ and $71^{\text {st }}$ days after the launch. This is to aerate the piles and allow better degradation of the organic matter. The piles are watered regularly to maintain a humidity level of 50\% [8]. The humidity level is obtained after drying in an oven at $105^{\circ} \mathrm{C}$ for about 24 hours. During the composting process, the temperature was measured every day (from the $1^{\text {st }}$ to the $107^{\text {th }}$ day) using JEULIN TYPE K electronic thermometers, precision $10^{-1}$, equipped with a thermometric probe. The temperature value is an average of 6 measurements taken along the length of the windrow, on each side [10]; and at varying depths $(0.5 ; 1.0 ; 1,5$ and $2.0 \mathrm{~m})$. The selected site is the platform of the NGO ENPRO located in the Adidogomé district in Lomé in Togo $\left(6^{\circ} 10^{\prime} 12.0^{\prime \prime} \mathrm{N} ; 1^{\circ} 10^{\prime} 53.9^{\prime \prime} \mathrm{E}\right)$.

\subsection{Sampling and Characterization of the Compost and Soil of the Experimental Site}

After 3, 4, 5 and 6 months from the start of composting, 2 heaps of each type of compost (at a rate of $10 \mathrm{~kg}$ per heap) were taken for screening. On average, $15 \mathrm{~kg}$ of compost is obtained after screening $20 \mathrm{~kg}$ of raw compost using a $5 \mathrm{~mm}$ mesh. The soil of the experimental site was also collected in different places and at depths of $0-20 \mathrm{~cm}$ (to constitute a single sample for analysis).

The methods for determining some chemical parameters of the different samples (soil and composts) are grouped below (Table 2). All measurements have been duplicated.

\subsection{Assessment of the Phytotoxicity of Composts}

Germination tests were carried out in triplicate on maize (Zea mays L.), in Lomé between September and October 2019, in order to assess the phytotoxicity of the composts [13]. The tests are carried out in plastic jars $10 \mathrm{~cm}$ in diameter and 8 $\mathrm{cm}$ in height, in the laboratory and at room temperature (Table 3) with regular daily watering with $50 \mathrm{~mL}$ of running water in order to maintain the rate of humidity between $60 \%$ and $80 \%$ of the field capacity. 
Table 1. Composition of windrows.

\begin{tabular}{cccc}
\hline & Household garbage $(\mathrm{kg})$ & Pineapple waste $(\mathrm{kg})$ & Animal litter + straw $(\mathrm{kg})$ \\
\hline Compost substrates $\mathrm{N}^{\circ} 1$ & 600 & 0 & 0 \\
Ccompost substrates $\mathrm{N}^{\circ} 2$ & 300 & 300 & 0 \\
Compost substrates $\mathrm{N}^{\circ} 3$ & 0 & 0 & 600 \\
\hline
\end{tabular}

Table 2. Methods for determining the chemical parameters of composts.

\begin{tabular}{|c|c|c|}
\hline Parameters & Materials and methods & References or standard \\
\hline Hydrogen potential & $\begin{array}{l}\text { Ratio 1/5 (Compost/distilled water) JEULIN } 701296 \text { pH meter INITIO. } \\
\text { Accuracy: } 10^{-2}\end{array}$ & $\begin{array}{l}\text { AFNOR NF ISO 10-390, } \\
2005\end{array}$ \\
\hline Electrical conductivity (EC) & $\begin{array}{l}\text { Ratio } 1 / 5 \text { (Compost/distilled water). CTA JEULIN } 701328 \text { conductivity meter } \\
\text { INITIO. Accuracy: } 10^{-2}\end{array}$ & $\begin{array}{l}\text { AFNOR NF ISO 10-390, } \\
2005\end{array}$ \\
\hline Total Organic Carbon (TOC) & $\begin{array}{l}\text { Oxidation of organic matter ( } 1 \mathrm{M} \text { potassium dichromate in acidic } \mathrm{H}_{2} \mathrm{SO}_{4} \text { medium). } \\
\text {-Reduction of the excess of potassium dichromate by an excess of double ferrous iron } \\
\text { and ammonium sulphate solution at } 0.5 \mathrm{~N} \text { dosed in return with dichromate }(1 \mathrm{M})\end{array}$ & {$[11]$} \\
\hline Organic matter $(\mathrm{OM})$ & $\begin{array}{l}\text { Baking at } 550^{\circ} \mathrm{C} \text { for } 2 \text { hours. Weight difference between the mass of dry waste and the } \\
\text { mass of calcined waste }\end{array}$ & [10] \\
\hline Total nitrogen Kjeldahl, (TNK) & $\begin{array}{l}\text {-Mineralization in an acidic medium and in the presence of a catalyst }\left(\mathrm{K}_{2} \mathrm{SO}_{4} \text { and } \mathrm{Se}\right) \\
\text {-Distillation after neutralization of the excess acid with } 30 \% \text { sodium hydroxide } \\
\text { solution } \\
\text {-Titration of the distillate with a sodium hydroxide solution }(0.1 \mathrm{M}) \text { in the presence of } \\
\text { methyl red }\end{array}$ & AFNOR NF T 90-110 \\
\hline Phosphorus (P) & $\begin{array}{l}\text { Extraction of compost with sulfuric acid at } 15 \% \text { by volume } \\
\text {-Spectroscopic assay at } 660 \mathrm{~nm}\end{array}$ & {$[12]$} \\
\hline $\begin{array}{l}\text { Potassium }(\mathrm{P}) \text {, calcium }(\mathrm{Ca}) \\
\text { magnesium }(\mathrm{Mg}) \text {, sodium }(\mathrm{Na})\end{array}$ & $\begin{array}{l}\text { Mineralization of hot compost samples and aqua regia }\left(\mathrm{HNO}_{3}+\mathrm{HCl}\right) \\
\text {-Determination by flame atomic absorption spectrophotometry }\end{array}$ & $\begin{array}{l}\text { AFNOR NF ISO } 11460 \\
\text { of June } 1995 .\end{array}$ \\
\hline
\end{tabular}

Table 3. Weather data for the period of phytotoxicity tests (source: historique-Météo.net).

\begin{tabular}{cccccccc}
\hline & $\begin{array}{c}\text { Mean } \\
\text { temperature }\left({ }^{\circ} \mathrm{C}\right)\end{array}$ & $\begin{array}{c}\text { Maximum } \\
\text { temperature }\left({ }^{\circ} \mathrm{C}\right)\end{array}$ & $\begin{array}{c}\text { Minimum } \\
\text { temperature }\left({ }^{\circ} \mathrm{C}\right)\end{array}$ & $\begin{array}{c}\text { Temperature } \\
\text { variation }\left({ }^{\circ} \mathrm{C}\right)\end{array}$ & $\begin{array}{c}\text { Cloud } \\
\text { cover }(\%)\end{array}$ & $\begin{array}{c}\text { Duration of Duration of } \\
\text { the day } \\
\text { the night }\end{array}$ \\
\hline September 2019 & 27 & 29 & 24 & 5 & 69 & $12: 14: 0$ & $11: 46: 0$ \\
October 2019 & 28 & 30 & 26 & 4 & 61 & $12: 04: 0$ & $11: 56: 0$ \\
\hline
\end{tabular}

Phytotoxicity is a peculiarity of composts which makes it possible to evaluate their maturity [13]. Ten (10) maize seeds (Zea mays L., var. IKENE) considered as a staple crop in Togo, are germinated, at a depth of 2 to $3 \mathrm{~mm}$, with the treatments in Table 4 [14]. These treatments are made for the three types of compost and at 3, 4, 5 and 6 months of composting.

The number of germinated seeds is counted after 6 days [13]. The germination rate, evaluated as a percentage, is calculated according to formula (1).

$$
\text { Germination rate }(\%)=100 \times \frac{\text { number of germinated seeds }}{\text { Number of seeds sown }}
$$

The results of the control treatment were taken as a reference and considered as $100 \%$. 
Table 4. Different treatment for the phytotoxicity tests.

\begin{tabular}{lccccc}
\hline & $\begin{array}{c}\text { To treatment } \\
\text { (sand only) }\end{array}$ & $\begin{array}{c}\mathrm{T}_{1} \text { treatment } \\
(3 / 4 \text { sand }+1 / 4 \text { compost) }\end{array}$ & $\begin{array}{c}\mathrm{T}_{2} \text { treatment } \\
(1 / 2 \text { sand }+1 / 2 \text { compost })\end{array}$ & $\begin{array}{c}\mathrm{T}_{3} \text { treatment } \\
(1 / 4 \text { sand }+3 / 4 \text { compost })\end{array}$ & $\begin{array}{c}\mathrm{T}_{4} \text { treatment } \\
\text { (compost only) }\end{array}$ \\
\hline Volume of sand $\left(\mathrm{cm}^{3}\right)$ & 400 & 300 & 200 & 100 & 400 \\
compost volume $\left(\mathrm{cm}^{3}\right)$ & 0 & 100 & 200 & 300 & 0 \\
\hline
\end{tabular}

\subsection{Evaluation of the Effects of Composts on the Agronomic Parameters of Maize}

\subsubsection{The Experimental Site: Location and Climatic Situation}

The experimental tests are carried out on a site preserved from any agricultural activity, for more than ten years, in the region of the plateaux in Kpalimé $\left(6^{\circ} 54^{\prime} 00^{\prime \prime}\right.$ North latitude, $0^{\circ} 37^{\prime} 59^{\prime \prime}$ East longitude and altitude of $225 \mathrm{~m}$ above sea level). The site is a land of $600 \mathrm{~m}^{2}\left(6^{\circ} 55^{\prime} 36.3^{\prime \prime}\right.$ latitude North and $0^{\circ} 37^{\prime} 52.3^{\prime \prime}$ longitude East), fenced and therefore protected from parasitic intrusions by animals. The site enjoys a tropical climate with heavy rainfall. The average temperature in Kpalimé is $26.0^{\circ} \mathrm{C}$ and the average annual precipitation is $1446 \mathrm{~mm}$ (Figure 1).

\subsubsection{Chemical Characteristics of the Soil}

Table 5 summarizes the chemical characteristics of the soil used for the agronomic trials.

\subsubsection{The Experimental Protocol}

The device used has 24 elementary plots corresponding to 8 treatments (Table 4) distributed randomly (Fischer block). Each treatment is repeated 3 times (Figure 2). The basic plots are separated from each other by an alley 0.7 meters wide, which serves as a passage during regular watering. Each elementary corn plot (with the walkways) occupies an area of approximately $6 \mathrm{~m}^{2}(3.5 \mathrm{~m}$ long by $1.7 \mathrm{~m}$ wide). This device is repeated 4 times $\left(\mathrm{M}_{3}, \mathrm{M}_{4}, \mathrm{M}_{5}\right.$ and $\mathrm{M}_{6}$ respectively 3, 4 , 5 and 6 months after composting). In total, the agronomic trials took place on 96 plots bordered by four walls that protect the crops throughout the trials.

The experiment was carried out for 6 months, according to the standard plan shown in Figure 2.

The first 4 months were devoted to $\mathrm{M}_{3}$ and $\mathrm{M}_{4}$. Two months later, the sowing of $M_{5}$ and $M_{6}$ takes place. The composts are applied at two doses (10 t/ha and 5 $\mathrm{t} / \mathrm{ha}$ ) and the chemical fertilizer at a dose of $200 \mathrm{~kg} / \mathrm{ha}$ in accordance with the recommendations of the Togolese Institute for Agronomic Research (ITRA) and the Institute of Advice and Technical Support (ICAT) to farmers (Table 6).

The plots are prepared one week before sowing and benefit from an irrigation of $30 \mathrm{~L} /$ plot three days before sowing depending on the retention capacity of the soil. The sowing is carried out with spacings of $60 \mathrm{~cm} \times 40 \mathrm{~cm}$ at the rate of 4 seeds per pocket. The stripping 2 weeks after sowing made it possible to maintain two plants per pocket. During the trial period, each plot benefited from three manual weeding 14 days, 35 days and 56 days after sowing. Two insecticide 
treatments, suitable for growing corn, are applied to the plots 6 and 10 weeks after sowing to rid the crops of pests.

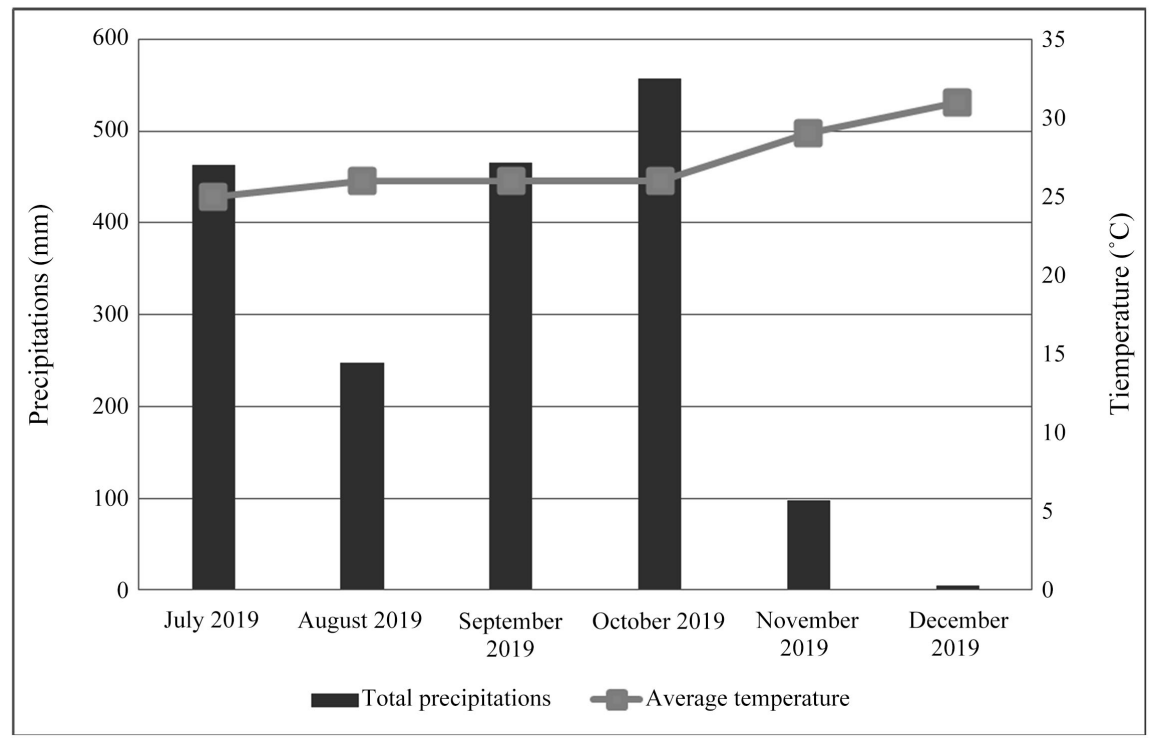

Figure 1. Monthly evolution of temperature and rainfall during the period of agronomic trials (source: historique-Météo.net).

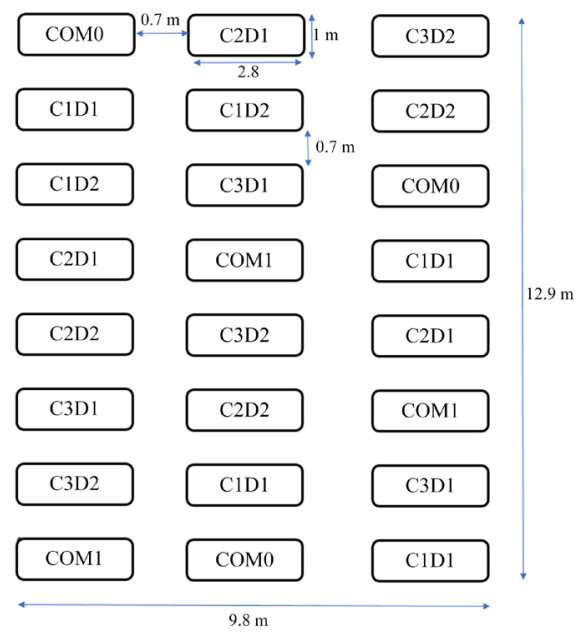

Figure 2. Standard sowing plan.

Table 5. Chemical characteristics of the soil.

\begin{tabular}{ccccccccc}
\hline & $\begin{array}{c}\text { TOM } \\
\left(\%_{\mathrm{ms}}\right)\end{array}$ & $\begin{array}{c}\text { TNK } \\
\left(\%_{\mathrm{ms}}\right)\end{array}$ & $\begin{array}{c}\text { TOC } \\
\left(\%_{\mathrm{ms}}\right)\end{array}$ & $\mathrm{C} / \mathrm{N}$ & $\mathrm{pH}$ & $\begin{array}{c}\mathrm{EC} \\
\left(\mu \mathrm{S} \cdot \mathrm{cm}^{-1}\right)\end{array}$ & $\begin{array}{c}\mathrm{P} \\
\left(\mathrm{mg}^{-1} \mathbf{g}_{\mathrm{m} . \mathrm{s}}\right)\end{array}$ & $\begin{array}{c}\mathrm{K} \\
\left(\mathrm{mg} \cdot \mathrm{g}^{-1} \mathrm{~m} . \mathrm{s}\right)\end{array}$ \\
\hline Content & $2.02 \pm 0.20$ & $0.07 \pm 0.03$ & $1.2 \pm 0.30$ & $16.7 \pm 0.3$ & $8.5 \pm 0.4$ & $80.0 \pm 6.0$ & $1.83 \pm 0.06$ & $0.07 \pm 0.01$ \\
\hline
\end{tabular}

Table 6. Characteristics of the treatments studied in the field trials.

\begin{tabular}{ccccccccc}
\hline & & & \multicolumn{2}{c}{ Compost N ${ }^{\circ}$} & \multicolumn{2}{c}{ Compost N $^{\circ} 2$} & \multicolumn{2}{c}{ Compost N $^{\circ}$} \\
\hline Type of amendment & $\mathrm{C}_{\mathrm{O}} \mathrm{M}_{0}$ & $\mathrm{C}_{\mathrm{O}} \mathrm{M}_{1}$ & $\mathrm{C}_{1} \mathrm{D}_{1}$ & $\mathrm{C}_{1} \mathrm{D}_{2}$ & $\mathrm{C}_{2} \mathrm{D}_{1}$ & $\mathrm{C}_{2} \mathrm{D}_{2}$ & $\mathrm{C}_{3} \mathrm{D}_{1}$ & $\mathrm{C}_{3} \mathrm{D}_{2}$ \\
\hline $\begin{array}{c}\text { Amount of } \\
\text { amendments }\end{array}$ & $\begin{array}{c}\text { No amendment } \\
\text { (Control) }\end{array}$ & $\begin{array}{c}200 \mathrm{~kg} / \mathrm{ha} \text { of chemical } \\
\text { fertilizer }\end{array}$ & $10 \mathrm{t} / \mathrm{ha}$ & $5 \mathrm{t} / \mathrm{ha}$ & $10 \mathrm{t} / \mathrm{ha}$ & $5 \mathrm{t} / \mathrm{ha}$ & $10 \mathrm{t} / \mathrm{ha}$ & $5 \mathrm{t} / \mathrm{ha}$ \\
\hline
\end{tabular}


Daily watering at the rate of $30 \mathrm{~L} /$ plot or natural rains (a total of $1733 \mathrm{~mm}$ of water for $M_{3}$ and $M_{4}$ and $1125 \mathrm{~mm}$ of water for $M_{5}$ and $M_{6}$ ), from sowing until 90 days after seedlings, allowed the plants to benefit from a good water regime. The average temperature during the period of the first test is $26^{\circ} \mathrm{C} \pm 1^{\circ} \mathrm{C}$ and that of the second test is $28^{\circ} \mathrm{C} \pm 2^{\circ} \mathrm{C}$. The rainfall data for the test period are shown (Figure 1).

\subsubsection{Measurement of Physiological and Agronomic Parameters}

The height of the plants and the physiological parameter of growth are evaluated at 3, 6 and 9 weeks after sowing. 120 days after sowing, the harvest is carried out. The grain yields and the 1000 grain weight of the different treatments are evaluated. Equation (2) is used to calculate the grain yield.

$$
\text { Yield }=M \times \frac{100-G_{f}}{100-S_{h}}
$$

Yield (in tonnes/hectare);

$M=$ Mass of grains (ton) harvested per hectare;

$G_{f}=$ Grain moisture in the field (\%);

$S_{h}=$ Standard humidity (the humidity recommended for good grain preservation, $14 \%)$.

The 1000 grain weight is estimated by counting the grains of each replicate and weighing 1000 grains. The results are expressed in g.

\subsection{Statistical Treatment of Results}

The data collected was analyzed using XLSTAT software. These data were subjected to a two-tailed equality of expectations test. The means were compared using the Student-Newman-Keuls test at the $5 \%$ threshold. Values followed by the same letter are not significantly different (Duncan, $\mathrm{p} \leq 0.05$ ).

\section{Results and Discussion}

The maturity assessment of the three types of compost from $M_{3}$ to $M_{6}$ is based on the analysis of their physicochemical characteristics, their phytotoxic properties through the germination test and their physiological and agronomic parameters.

\subsection{Evolution of the Chemical Characteristics and Nutrients of Composts}

The $\mathrm{pH}$ and the $\mathrm{C} / \mathrm{N}$ ratio are the parameters most often used to assess the maturity of compost. The $\mathrm{pH}$ of the different types of compost from the end of the $3^{\text {rd }}$ month of composting varies from $7.4 \pm 0.1$ to $8.1 \pm 0.1$, corresponding to the $\mathrm{pH}$ of ripe composts. This is consistent with the results of the work of [15] and [6] whose $\mathrm{pH}$ values of mature composts are respectively between 7 and 8.1. However, taken in isolation, $\mathrm{pH}$ is not a relevant parameter to assess the maturity of a growing medium [11]. In this case, the $\mathrm{C} / \mathrm{N}$ ratio should be added. The values of the $\mathrm{C} / \mathrm{N}$ ratios for the three types of composts studied are between 6.2 
\pm 0.3 and $13.9 \pm 0.4$. These values are all below 15 , the threshold below which [12] consider compost to be ripe. The composts studied are therefore ripe.

But it is also believed by many authors that the $\mathrm{C} / \mathrm{N}$ ratio of mature compost decreases over time. The $\mathrm{C} / \mathrm{N}$ ratio of composts $\mathrm{N}^{\circ} 1$ and $\mathrm{N}^{\circ} 2$ gradually decreases from $\mathrm{M}_{3}$ to $\mathrm{M}_{6}\left(13.1 \pm 0.1\right.$ to $6.2 \pm 0.3$ for compost $\mathrm{N}^{\circ} 1$ and $13.9 \pm 0.4$ at $7.5 \pm$ 0.5 for compost $\mathrm{N}^{\circ} 2$ ). This corroborates the work of [16] who showed that the $\mathrm{C} / \mathrm{N}$ ratios of two household waste composts decrease regularly during the 246 days of composting (15.4 to 6.3 for the first and 13,1 to 6.0 for the second compost) (Table 7).

Table 7. Evolution of the chemical characteristics and nutrients of composts.

\begin{tabular}{|c|c|c|c|c|c|c|}
\hline & $\mathbf{M}_{3}$ & $\mathbf{M}_{4}$ & $\mathrm{M}_{5}$ & $M_{6}$ & (Toundou, 2017) & ENPRO \\
\hline \multicolumn{7}{|c|}{$\mathrm{pH}$} \\
\hline Compost $\mathrm{N}^{\circ} 1$ & $8.3 \pm 0.1^{\mathrm{a}}$ & $8.0 \pm 0.1^{\mathrm{a}}$ & $7.5 \pm 0.1^{\mathrm{a}}$ & $7.7 \pm 0.1^{\mathrm{a}}$ & & \\
\hline Compost $\mathrm{N}^{\circ} 2$ & $8.2 \pm 0.1^{\mathrm{a}}$ & $8.1 \pm 0.0^{\mathrm{a}}$ & $7.4 \pm 0.1^{\mathrm{a}}$ & $7.6 \pm 0.0^{\mathrm{a}}$ & $7.80-8.14$ & - \\
\hline Compost $\mathrm{N}^{\circ} 3$ & $8.1 \pm 0.1^{\mathrm{a}}$ & $8.1 \pm 0.1^{\mathrm{a}}$ & $7.4 \pm 0.0^{\mathrm{a}}$ & $7.7 \pm 0.1^{\mathrm{a}}$ & & \\
\hline \multicolumn{7}{|c|}{ Electrical conductivity $\left(\mathrm{mS} \cdot \mathrm{cm}^{-1}\right)$} \\
\hline Compost $\mathrm{N}^{\circ} 1$ & $3.43 \pm 0.06^{\mathrm{a}}$ & $3.13 \pm 0.06^{\mathrm{a}}$ & $3.37 \pm 0.06^{\mathrm{a}}$ & $4.03 \pm 0.06^{\mathrm{a}}$ & & \\
\hline Compost $\mathrm{N}^{\circ} 2$ & $4.13 \pm 0.06^{\mathrm{b}}$ & $4.03 \pm 0.06^{\mathrm{b}}$ & $4.50 \pm 0.00^{\mathrm{b}}$ & $4.10 \pm 0.00^{\mathrm{a}}$ & $1.297-3.080$ & - \\
\hline Compost $\mathrm{N}^{\circ} 3$ & $8.03 \pm 0.06^{\mathrm{c}}$ & $7.93 \pm 0.06^{\mathrm{c}}$ & $4.60 \pm 0.10^{\mathrm{b}}$ & $4.03 \pm 0.06^{\mathrm{a}}$ & & \\
\hline \multicolumn{7}{|c|}{ Total organic matter (\% m.s) } \\
\hline Compost $\mathrm{N}^{\circ} 1$ & $19.3 \pm 0.0^{\mathbf{a}}$ & $18.7 \pm 0.1^{\mathrm{a}}$ & $16.6 \pm 0.1^{\mathrm{a}}$ & $14.9 \pm 0.4^{\mathrm{a}}$ & & \\
\hline Compost $\mathrm{N}^{\circ} 2$ & $22.1+0.1^{b}$ & $21.3 \pm 0.4^{\mathrm{b}}$ & $19.3 \pm 0.2^{\mathrm{b}}$ & $18.5 \pm 0.5^{\mathrm{b}}$ & $11.0-15.2$ & $26.1 \pm 0.7$ \\
\hline Compost $\mathrm{N}^{\circ} 3$ & $35.1 \pm 0.1^{\mathrm{c}}$ & $40.6 \pm 0.1^{c}$ & $35.8 \pm 0.4^{c}$ & $40.4 \pm 0.9^{c}$ & & \\
\hline \multicolumn{7}{|c|}{ Total Organic Carbon (\% m.s) } \\
\hline Compost $\mathrm{N}^{\circ} 1$ & $11.2 \pm 0.0^{\mathrm{a}}$ & $10.9 \pm 0.1^{\mathrm{a}}$ & $9.7 \pm 0.1^{\mathrm{a}}$ & $8.7 \pm 0.2^{\mathrm{a}}$ & & \\
\hline Compost $\mathrm{N}^{\circ} 2$ & $12.8 \pm 0.1^{\mathrm{b}}$ & $12.4 \pm 0.2^{\mathrm{b}}$ & $11.2 \pm 0.1^{\mathrm{b}}$ & $10.7 \pm 0.3^{b}$ & $6.39-8.83$ & $12 \pm 2$ \\
\hline Compost $\mathrm{N}^{\circ} 3$ & $20.4 \pm 0.1^{c}$ & $23.6 \pm 0.1^{c}$ & $20.8 \pm 0.2^{c}$ & $23.5 \pm 0.5^{c}$ & & \\
\hline \multicolumn{7}{|c|}{ Total nitrogen Kjeldahl (\% m.s) } \\
\hline Compost $\mathrm{N}^{\circ} 1$ & $0.86 \pm 0.01^{\mathrm{a}}$ & $0.88 \pm 0.04^{\mathrm{a}}$ & $1.05 \pm 0.01^{\mathrm{a}}$ & $1.40 \pm 0.04^{\mathrm{a}}$ & & \\
\hline Compost $\mathrm{N}^{\circ} 2$ & $0.92 \pm 0.02^{\mathrm{a}}$ & $0.93 \pm 0.03^{\mathrm{a}}$ & $1.09 \pm 0.03^{\mathrm{a}}$ & $1.44 \pm 0.05^{\mathrm{a}}$ & $0.41-1.20$ & $\begin{array}{c}0.50 \pm \\
0.02\end{array}$ \\
\hline Compost $\mathrm{N}^{\circ} 3$ & $2.07 \pm 0.03^{b}$ & $2.11 \pm 0.01^{b}$ & $2.04 \pm 0.05^{\mathrm{b}}$ & $2.44 \pm 0.45^{\mathrm{b}}$ & & \\
\hline \multicolumn{7}{|c|}{$\mathrm{C} / \mathrm{N}$ ratio } \\
\hline Compost $\mathrm{N}^{\circ} 1$ & $13.10 \pm 0.11^{\mathrm{a}}$ & $12.33 \pm 0.51^{\mathrm{a}}$ & $9.23 \pm 0.01^{\mathrm{a}}$ & $6.20 \pm 0.31^{\mathrm{a}}$ & & \\
\hline Compost $\mathrm{N}^{\circ} 2$ & $13.93 \pm 0.40^{\mathrm{a}}$ & $13.28 \pm 0.63^{b}$ & $10.28 \pm 0.14^{\mathrm{b}}$ & $7.46 \pm 0.45^{\mathrm{b}}$ & $7.35-15.87$ & 24.7 \\
\hline Compost $\mathrm{N}^{\circ} 3$ & $9.83 \pm 0.17^{\mathrm{b}}$ & $11.16 \pm 0.04^{c}$ & $10.20 \pm 0.14^{\mathrm{b}}$ & $9.63 \pm 0.50^{\mathfrak{c}}$ & & \\
\hline \multicolumn{7}{|c|}{ Total phosphorus $\left(\mathrm{mg} \cdot \mathrm{g}^{-1}\right)$} \\
\hline Compost $\mathrm{N}^{\circ} 1$ & $1.54 \pm 0.08^{\mathrm{a}}$ & $1.85 \pm 0.07^{\mathrm{a}}$ & $2.53 \pm 0.04^{\mathrm{a}}$ & $2.65 \pm 0.21^{\mathrm{a}}$ & & \\
\hline Compost $\mathrm{N}^{\circ} 2$ & $1.93 \pm 0.10^{\mathrm{b}}$ & $3.58 \pm 0.06^{\mathrm{b}}$ & $3.80 \pm 0.14^{\mathrm{b}}$ & $4.55 \pm 0.21^{\mathrm{b}}$ & $2.6-4.5$ & $0.3 \pm 0.0$ \\
\hline Compost $\mathrm{N}^{\circ} 3$ & $3.18 \pm 0.04^{c}$ & $3.55 \pm 0.07^{b}$ & $4.23 \pm 0.10^{c}$ & $5.40 \pm 0.14^{c}$ & & \\
\hline
\end{tabular}




\section{Continued}

\begin{tabular}{|c|c|c|c|c|c|c|}
\hline \multicolumn{7}{|c|}{ Potassium $\left(\mathrm{mg} \cdot \mathrm{g}^{-1}\right)$} \\
\hline Compost $\mathrm{N}^{\circ} 1$ & $8.8 \pm 0.1^{\mathrm{a}}$ & $11.2 \pm 0.1^{\mathrm{a}}$ & $12.7 \pm 0.1^{\mathrm{a}}$ & $19.9 \pm 0.1^{\mathrm{a}}$ & & \\
\hline Compost $\mathrm{N}^{\circ} 2$ & $9.6 \pm 0.2^{\mathrm{b}}$ & $10.0 \pm 0.1^{\mathrm{b}}$ & $13.3 \pm 0.2^{\mathrm{a}}$ & $20.5 \pm 0.2^{\mathrm{a}}$ & $4.2-6.0$ & $4.0 \pm 0.0$ \\
\hline Compost $\mathrm{N}^{\circ} 3$ & $10.4 \pm 0.1^{\mathrm{c}}$ & $10.9 \pm 0.1^{\mathrm{a}}$ & $18.5 \pm 0.1^{\mathrm{b}}$ & $19.8 \pm 0.1^{\mathrm{a}}$ & & \\
\hline \multicolumn{7}{|c|}{ Calcium $\left(\mathrm{mg} \cdot \mathrm{g}^{-1}\right)$} \\
\hline Compost $\mathrm{N}^{\circ} 1$ & $26.8 \pm 0.3^{\mathrm{a}}$ & $30.9 \pm 0.1^{\mathrm{a}}$ & $31.4 \pm 0.1^{\mathrm{a}}$ & $31.4 \pm 0.2^{\mathrm{a}}$ & & \\
\hline Compost $\mathrm{N}^{\circ} 2$ & $23.3 \pm 0.1^{b}$ & $28.8 \pm 0.1^{\mathrm{a}}$ & $30.1 \pm 0.4^{\mathrm{a}}$ & $30.7 \pm 0.1^{\mathrm{a}}$ & $9.2-16.3$ & $29.1 \pm 0.7$ \\
\hline Compost $\mathrm{N}^{\circ} 3$ & $22.1 \pm 0.4^{\mathrm{b}}$ & $30.5 \pm 0.1^{\mathrm{a}}$ & $30.9 \pm 0.2^{\mathrm{a}}$ & $30.9 \pm 0.1^{\mathrm{a}}$ & & \\
\hline \multicolumn{7}{|c|}{ Magnesium $\left(\mathrm{mg} \cdot \mathrm{g}^{-1}\right)$} \\
\hline Compost $\mathrm{N}^{\circ} 1$ & $2.50 \pm 0.42^{\mathrm{a}}$ & $2.95 \pm 0.21^{\mathrm{a}}$ & $2.95 \pm 0.21^{\mathrm{a}}$ & $3.25 \pm 0.21^{\mathrm{a}}$ & & \\
\hline Compost $\mathrm{N}^{\circ} 2$ & $2.60 \pm 0.14^{\mathrm{a}}$ & $3.05 \pm 0.21^{\mathrm{a}}$ & $3.15 \pm 0.21^{\mathrm{a}}$ & $3.25 \pm 0.35^{\mathrm{a}}$ & - & $2.1 \pm 0.2$ \\
\hline Compost $\mathrm{N}^{\circ} 3$ & $6.40 \pm 0.14^{b}$ & $6.65 \pm 0.21^{b}$ & $6.95 \pm 0.21^{\mathrm{b}}$ & $6.85 \pm 0.07^{b}$ & & \\
\hline \multicolumn{7}{|c|}{ Sodium $\left(\mathrm{mg} \cdot \mathrm{g}^{-1}\right)$} \\
\hline Compost $\mathrm{N}^{\circ} 1$ & $2.10 \pm 0.14^{\mathrm{a}}$ & $2.35 \pm 0.07^{\mathrm{a}}$ & $2.45 \pm 0.07^{\mathrm{a}}$ & $2.70 \pm 0.28^{\mathrm{a}}$ & & \\
\hline Compost $\mathrm{N}^{\circ} 2$ & $1.60 \pm 0.14^{\mathrm{b}}$ & $2.35 \pm 0.35^{\mathrm{a}}$ & $2.50 \pm 0.14^{\mathrm{a}}$ & $2.75 \pm 0.07^{\mathrm{a}}$ & - & - \\
\hline Compost $\mathrm{N}^{\circ} 3$ & $6.15 \pm 0.21^{\mathrm{c}}$ & $7.10 \pm 0.00^{\mathrm{b}}$ & $7.45 \pm 0.21^{\mathrm{b}}$ & $7.65 \pm 0.21^{\mathrm{b}}$ & & \\
\hline
\end{tabular}

Vertically, the values followed by the same letter are not significantly different (Duncan, $\mathrm{p} \leq 0.05$ ).

According to the same authors, the evolution of the $\mathrm{C} / \mathrm{N}$ ratio is strongly linked to the biodegradation of organic matter which results in the elimination of carbon in the form of $\mathrm{CO}_{2}$ and an increase in the concentrations of mineral elements essential for the development of plants (N, P, K).

The $C / N$ ratio of compost $N^{\circ} 3$ after an increase of $14 \%$ between $M_{3}$ and $M_{4}$, has experienced a gradual decrease from $\mathrm{M}_{5}$. This development suggests that compost $\mathrm{N}^{\circ} 3$ continued its fermentation process between $\mathrm{M}_{3}$ and $\mathrm{M}_{4}$ before entering the maturation phase from $\mathrm{M}_{5}$. This development would be due to the nature of the substrates used (animal litter).

\subsection{Phytotoxicity Test}

Maturity is an essential criterion for evaluating the agronomic quality of compost and the toxicity linked to the incorporation of composts into the soil. Immature compost causes a phenomenon of phytotoxicity which has a negative effect on seed germination and plant growth [5]. Germination tests help to establish a relationship between the amount of compost and the rate of germination. Overall, the germination rate of the three types of compost decreases when the dose of compost in the different treatments increases (Table 8). This result shows that germination is suppressed with an increase in the dose of compost. This is corroborated by the work of [12] who showed that the repressive effect of compost is not only linked to its characteristics, but also depends on the dose applied. 
Table 8. Evolution of the germination rate of the different compost treatments.

\begin{tabular}{|c|c|c|c|c|c|c|}
\hline & $\mathrm{M}_{3}$ & $\mathrm{M}_{4}$ & $\mathrm{M}_{5}$ & $\mathrm{M}_{6}$ & [14] & [7] \\
\hline \multicolumn{7}{|c|}{ Treatment $T_{1}(3 / 4$ sand $+1 / 4$ compost $)$} \\
\hline Compost $\mathrm{N}^{\circ} 1$ & $100 \%$ & $100 \%$ & $100 \%$ & $100 \%$ & & \\
\hline Compost $\mathrm{N}^{\circ} 2$ & $90 \%$ & $90 \%$ & $90 \%$ & $100 \%$ & $84 \%-95 \%$ & $90 \%$ \\
\hline Compost $\mathrm{N}^{\circ} 3$ & $70 \%$ & $70 \%$ & $80 \%$ & $100 \%$ & & \\
\hline \multicolumn{7}{|c|}{ Treatment $T_{2}$ (1/2 sand $+1 / 2$ compost $)$} \\
\hline Compost $\mathrm{N}^{\circ} 1$ & $80 \%$ & $70 \%$ & $100 \%$ & $100 \%$ & & \\
\hline Compost $\mathrm{N}^{\circ} 2$ & $90 \%$ & $90 \%$ & $90 \%$ & $100 \%$ & - & $80 \%$ \\
\hline Compost $\mathrm{N}^{\circ} 3$ & $10 \%$ & $60 \%$ & $70 \%$ & $100 \%$ & & \\
\hline \multicolumn{7}{|c|}{ Treatment $\mathrm{T}_{3}(1 / 4$ sand $+3 / 4$ compost $)$} \\
\hline Compost $\mathrm{N}^{\circ} 1$ & $70 \%$ & $70 \%$ & $100 \%$ & $90 \%$ & & \\
\hline Compost $\mathrm{N}^{\circ} 2$ & $90 \%$ & $90 \%$ & $90 \%$ & $90 \%$ & $31 \%-55 \%$ & - \\
\hline Compost $\mathrm{N}^{\circ} 3$ & $20 \%$ & $0 \%$ & $60 \%$ & $50 \%$ & & \\
\hline \multicolumn{7}{|c|}{ Treatment $\mathrm{T}_{4}$ (only compost) } \\
\hline Compost $\mathrm{N}^{\circ} 1$ & $70 \%$ & $60 \%$ & $90 \%$ & $90 \%$ & & \\
\hline Compost $\mathrm{N}^{\circ} 2$ & $40 \%$ & $30 \%$ & $90 \%$ & $100 \%$ & $27 \%-45 \%$ & $80 \%$ \\
\hline Compost $\mathrm{N}^{\circ} 3$ & $0 \%$ & $0 \%$ & $90 \%$ & $50 \%$ & & \\
\hline \multicolumn{7}{|c|}{ Control treatment (only sandl) } \\
\hline & & & & & $98 \%$ & $80 \%$ \\
\hline
\end{tabular}

The results of the germination rate of composts $\mathrm{N}^{\circ} 1$ and $\mathrm{N}^{\circ} 2$ clearly show that the $T_{1}$ and $T_{2}$ treatments give germination rates of the two types of compost which are significantly high and higher or close to the $80 \%$ recommended by the AFNOR standard (2005). It can therefore be concluded that at a dose of $25 \%$ or less, a 3-month composting would suffice to avoid a reduction in the germination rate in the case of household and similar waste. In addition, the evolution of the two types of composts from $M_{3}$ to $M_{6}$ for the two types of treatment shows a certain stability in the germination rates (Table 6). In addition, these values are close to the results of the phytotoxicity tests carried out on maize by [14] and [7]. For these authors, the results of their work testify to the maturity of composts and their low concentration of phytotoxic substances. All these data show that composts $\mathrm{N}^{\circ} 1$ and $\mathrm{N}^{\circ} 2$ would be ripe at the end of the 3rd month of composting as shown by the work of [13] who admitted that mature compost has no phytotoxic effects on seed germination and plant growth. These results also show that the germination rates of composts $\mathrm{N}^{\circ} 1$ and $\mathrm{N}^{\circ} 2$ are all equal to $100 \%$ after 6 months of composting. This shows that after 6 months of composting, household refuse and similar composts are really ripe and do not exhibit phytotoxic effects on the germination of corn seeds (Zea mays L., var. IKENE).

The germination rate of compost $\mathrm{N}^{\circ}$, between $\mathrm{M}_{3}$ and $\mathrm{M}_{6}$ for the $\mathrm{T}_{1}$ treatment, reaches at least $80 \%$ from $\mathrm{M}_{5}$ (Table 8 ). This threshold is only reached 
from $\mathrm{M}_{6}$ for $\mathrm{T}_{2}$ treatment. It can therefore be concluded that at a dose of $25 \%$ or less, composting of at least 5 months is necessary to avoid a reduction in the germination rate in the case of household and similar waste. In addition, whatever the treatment, the germination rate of compost $\mathrm{N}^{\circ} 3$ is less than $80 \%$ between $M_{3}$ and $M_{4}$. This could be explained by the relatively high value of the electrical conductivity of this compost $\left(8.1 \pm 0.1 \mathrm{mS} \cdot \mathrm{cm}^{-1}\right.$ in $\mathrm{M}_{3}$ and $7.9 \pm 0.1$ $\mathrm{mS} \cdot \mathrm{cm}^{-1}$ in $\mathrm{M}_{4}$ ), likely to create a repressive effect on seed germination and plant growth, as some authors have shown. According to [10] an electrical conductivity between 2 and $3 \mathrm{mS} \cdot \mathrm{cm}^{-1}$ is an acceptable level for the application of mature compost. Although [12] showed that compost with an electrical conductivity close to $5 \mathrm{mS} \cdot \mathrm{cm}^{-1}$ has no remarkable phytotoxic effects on garlic seeds, the germination rate of which $(74 \%)$ remains correct, the fact remains that the relatively high value of the electrical conductivity of compost $\mathrm{N}^{\circ} 3$ between $\mathrm{M}_{3}$ and $\mathrm{M}_{4}$ could have a phytotoxic effect on seed germination. In addition, the significant drop in conductivity from $M_{5}\left(67 \%\right.$ between $M_{4}$ and $M_{5}$ ) coincides with a significant increase in the germination rate. These results show that compost $\mathrm{N}^{\circ} 3$ has phytotoxic effects on the germination of corn seeds (Zea mays L., var. IKENE) between $M_{3}$ and $M_{4}$. These effects are strongly attenuated in $M_{5}$ to practically disappear in $\mathrm{M}_{6}$. The results of the germination rate of compost $\mathrm{N}^{\circ} 3$ also show that for the $T_{1}$ and $T_{2}$ treatments, the germination rate after 6 months of composting is equal to $100 \%$. Like composts $\mathrm{N}^{\circ} 1$ and $\mathrm{N}^{\circ} 2$, animal litter composts are effectively ripe after 6 months of composting and therefore do not exhibit phytotoxic effects on the germination of corn seeds (Zea mays L., var. IKENE).

\subsection{Effects of Composts Maturity on Corn Growth and Agronomic Parameters}

\subsubsection{Plant Height}

The use of composts generally improves plant growth [10]. At the end of the $3^{\text {rd }}$ week after sowing, the 3- and 4-month-old composts, apart from the $\mathrm{C}_{1} \mathrm{D}_{2}$ compost (household waste compost at a dose of $5 \mathrm{t} / \mathrm{ha}$ ), have plant heights less than or equal to the Control test, $\mathrm{C}_{0} \mathrm{M}_{0}$, having received no organic amendment while the 5- and 6-month composts show plant heights greater than or equal to the Control test, $\mathrm{C}_{0} \mathrm{M}_{0}$. The heights of the plants at the $6^{\text {th }}$ and $9^{\text {th }}$ weeks of growth under the different composts at the two doses of 5 and $10 \mathrm{t} / \mathrm{ha}$ are greater compared to the Control test, $\mathrm{C}_{0} \mathrm{M}_{0}$ (Table 9).

Table 9. Evolution of the height of the plants for the different treatments.

\begin{tabular}{ccccc}
\hline & $\mathbf{M}_{3}$ & $\mathbf{M}_{4}$ & $\mathbf{M}_{5}$ & $\mathbf{M}_{6}$ \\
\hline \multicolumn{5}{c}{ Week 3 $(\mathrm{cm})$} \\
$\mathrm{C}_{1} \mathrm{D}_{1}$ & $\mathbf{2 8}$ & $\mathbf{2 9}$ & $\mathbf{3 3}$ & $\mathbf{3 1}$ \\
& $(-9.7 \%)$ & $(-6.5 \%)$ & $(6.5 \%)$ & $(0 \%)$ \\
$\mathrm{C}_{1} \mathrm{D}_{2}$ & $\mathbf{3 2}$ & $\mathbf{3 2}$ & 37 & $\mathbf{3 8}$ \\
& $(3.2 \%)$ & $(3.2 \%)$ & $(19.4 \%)$ & $(22.6 \%)$ \\
$\mathrm{C}_{2} \mathrm{D}_{1}$ & $\mathbf{3 4}$ & 28 & 36 & 31 \\
& $(9.7 \%)$ & $(-9.7 \%)$ & $(16.1 \%)$ & $(0 \%)$ \\
\hline
\end{tabular}




\section{Continued}

\begin{tabular}{|c|c|c|c|c|}
\hline $\mathrm{C}_{2} \mathrm{D}_{2}$ & $\begin{array}{c}29 \\
(-6.5 \%)\end{array}$ & $\begin{array}{c}31 \\
(0 \%)\end{array}$ & $\begin{array}{c}36 \\
(16.1 \%)\end{array}$ & $\begin{array}{c}34 \\
(9.7 \%)\end{array}$ \\
\hline$C_{3} D_{1}$ & $\begin{array}{c}28 \\
(-9.7 \%)\end{array}$ & $\begin{array}{c}31 \\
(0 \%)\end{array}$ & $\begin{array}{c}34 \\
(9.7 \%)\end{array}$ & $\begin{array}{c}31 \\
(0 \%)\end{array}$ \\
\hline $\mathrm{C}_{3} \mathrm{D}_{2}$ & $\begin{array}{c}28 \\
(-9.7 \%)\end{array}$ & $\begin{array}{c}31 \\
(0 \%)\end{array}$ & $\begin{array}{c}34 \\
(9.7 \%)\end{array}$ & $\begin{array}{c}31 \\
(0 \%)\end{array}$ \\
\hline $\mathrm{C}_{\mathrm{O}} \mathrm{M}_{0}$ & $\begin{array}{c}31 \\
(0 \%)\end{array}$ & $\begin{array}{c}31 \\
(0 \%)\end{array}$ & $\begin{array}{c}31 \\
(0 \%)\end{array}$ & $\begin{array}{c}31 \\
(0 \%)\end{array}$ \\
\hline $\mathrm{C}_{\mathrm{O}} \mathrm{M}_{1}$ & $\begin{array}{c}33 \\
(6.5 \%)\end{array}$ & $\begin{array}{c}33 \\
(6.5 \%)\end{array}$ & $\begin{array}{c}33 \\
(6.5 \%)\end{array}$ & $\begin{array}{c}33 \\
(6.5 \%)\end{array}$ \\
\hline \multicolumn{5}{|c|}{ Week $6(\mathrm{~cm})$} \\
\hline$C_{1} D_{1}$ & $\begin{array}{l}107 \\
(0 \%)\end{array}$ & $\begin{array}{c}108 \\
(0.9 \%)\end{array}$ & $\begin{array}{c}133 \\
(24.3 \%)\end{array}$ & $\begin{array}{c}118 \\
(10.3 \%)\end{array}$ \\
\hline $\mathrm{C}_{1} \mathrm{D}_{2}$ & $\begin{array}{c}123 \\
(15.0 \%)\end{array}$ & $\begin{array}{c}126 \\
(17.8 \%)\end{array}$ & $\begin{array}{c}125 \\
(16.8 \%)\end{array}$ & $\begin{array}{c}132 \\
(23.4 \%)\end{array}$ \\
\hline $\mathrm{C}_{2} \mathrm{D}_{1}$ & $\begin{array}{c}117 \\
(9.3 \%)\end{array}$ & $\begin{array}{c}117 \\
(9.3 \%)\end{array}$ & $\begin{array}{c}125 \\
(16.8 \%)\end{array}$ & $\begin{array}{c}125 \\
(16.8 \%)\end{array}$ \\
\hline $\mathrm{C}_{2} \mathrm{D}_{2}$ & $\begin{array}{c}119 \\
(11.2 \%)\end{array}$ & $\begin{array}{c}117 \\
(9.3 \%)\end{array}$ & $\begin{array}{c}126 \\
(17.8 \%)\end{array}$ & $\begin{array}{c}131 \\
(22.4 \%)\end{array}$ \\
\hline $\mathrm{C}_{3} \mathrm{D}_{1}$ & $\begin{array}{c}129 \\
(20.6 \%)\end{array}$ & $\begin{array}{c}125 \\
(16.8 \%)\end{array}$ & $\begin{array}{c}141 \\
(31.8 \%)\end{array}$ & $\begin{array}{c}126 \\
(17.8 \%)\end{array}$ \\
\hline $\mathrm{C}_{3} \mathrm{D}_{2}$ & $\begin{array}{c}123 \\
(15.0 \%)\end{array}$ & $\begin{array}{c}116 \\
(8.4 \%)\end{array}$ & $\begin{array}{c}126 \\
(17.8 \%)\end{array}$ & $\begin{array}{c}127 \\
(18.7 \%)\end{array}$ \\
\hline $\mathrm{C}_{\mathrm{O}} \mathrm{M}_{0}$ & $\begin{array}{l}107 \\
(0 \%)\end{array}$ & $\begin{array}{l}107 \\
(0 \%)\end{array}$ & $\begin{array}{l}107 \\
(0 \%)\end{array}$ & $\begin{array}{l}107 \\
(0 \%)\end{array}$ \\
\hline $\mathrm{C}_{\mathrm{O}} \mathrm{M}_{1}$ & $\begin{array}{c}129 \\
(21.2 \%)\end{array}$ & $\begin{array}{c}129 \\
(21.2 \%)\end{array}$ & $\begin{array}{c}129 \\
(21.2 \%)\end{array}$ & $\begin{array}{c}129 \\
(21.2 \%)\end{array}$ \\
\hline \multicolumn{5}{|c|}{ Week $9(\mathrm{~cm})$} \\
\hline$C_{1} D_{1}$ & $\begin{array}{c}139 \\
(7.4 \%)\end{array}$ & $\begin{array}{c}142 \\
(8.3 \%)\end{array}$ & $\begin{array}{c}150 \\
(14.5 \%)\end{array}$ & $\begin{array}{c}143 \\
(9.2 \%)\end{array}$ \\
\hline $\mathrm{C}_{1} \mathrm{D}_{2}$ & $\begin{array}{c}130 \\
(-0.8 \%)\end{array}$ & $\begin{array}{l}131 \\
(0 \%)\end{array}$ & $\begin{array}{c}129 \\
(-1.5 \%)\end{array}$ & $\begin{array}{c}155 \\
(18.3 \%)\end{array}$ \\
\hline $\mathrm{C}_{2} \mathrm{D}_{1}$ & $\begin{array}{c}136 \\
(3.8 \%)\end{array}$ & $\begin{array}{c}134 \\
(2.3 \%)\end{array}$ & $\begin{array}{c}138 \\
(5.3 \%)\end{array}$ & $\begin{array}{c}143 \\
(9.2 \%)\end{array}$ \\
\hline $\mathrm{C}_{2} \mathrm{D}_{2}$ & $\begin{array}{c}139 \\
(7.4 \%)\end{array}$ & $\begin{array}{c}131 \\
(0 \%)\end{array}$ & $\begin{array}{c}137 \\
(4.6 \%)\end{array}$ & $\begin{array}{c}141 \\
(7.6 \%)\end{array}$ \\
\hline $\mathrm{C}_{3} \mathrm{D}_{1}$ & $\begin{array}{c}131 \\
(0 \%)\end{array}$ & $\begin{array}{c}148 \\
(13.0 \%)\end{array}$ & $\begin{array}{c}151 \\
(15.3 \%)\end{array}$ & $\begin{array}{c}152 \\
(16.0 \%)\end{array}$ \\
\hline $\mathrm{C}_{3} \mathrm{D}_{2}$ & $\begin{array}{c}144 \\
(9.9 \%)\end{array}$ & $\begin{array}{c}133 \\
(1.5 \%)\end{array}$ & $\begin{array}{c}136 \\
(3.8 \%)\end{array}$ & $\begin{array}{c}146 \\
(11.5 \%)\end{array}$ \\
\hline $\mathrm{C}_{\mathrm{O}} \mathrm{M}_{0}$ & $\begin{array}{c}131 \\
(0 \%)\end{array}$ & $\begin{array}{c}131 \\
(0 \%)\end{array}$ & $\begin{array}{c}131 \\
(0 \%)\end{array}$ & $\begin{array}{c}131 \\
(0 \%)\end{array}$ \\
\hline $\mathrm{C}_{\mathrm{O}} \mathrm{M}_{1}$ & $\begin{array}{c}152 \\
(16.0 \%)\end{array}$ & $\begin{array}{c}152 \\
(16.0 \%)\end{array}$ & $\begin{array}{c}152 \\
(16.0 \%)\end{array}$ & $\begin{array}{c}152 \\
(16.0 \%)\end{array}$ \\
\hline
\end{tabular}

$\mathrm{C}_{1} \mathrm{D}_{1}$ : Compost $\mathrm{N}^{\circ} 1$ to $10 \mathrm{t} / \mathrm{ha} ; \mathrm{C}_{1} \mathrm{D}_{2}$ : Compost $\mathrm{N}^{\circ} 1$ to $5 \mathrm{t} / \mathrm{ha} ; \mathrm{C}_{2} \mathrm{D}_{1}$ : Compost $\mathrm{N}^{\circ} 2$ to $10 \mathrm{t} / \mathrm{ha}_{2} \mathrm{D}_{2}$ : Compost $\mathrm{N}^{\circ} 2$ to $5 \mathrm{t} / \mathrm{ha} ; \mathrm{C}_{3} \mathrm{D}_{1}$ : Compost $\mathrm{N}^{\circ} 3$ to $10 \mathrm{t} / \mathrm{ha} ; \mathrm{C}_{3} \mathrm{D}_{2}$ : Compost $\mathrm{N}^{\circ} 3$ to $5 \mathrm{t} / \mathrm{ha} ; \mathrm{C}_{\mathrm{O}} \mathrm{M}_{0}$ : No organic growth; $\mathrm{C}_{\mathrm{O}} \mathrm{M}_{1}: 200 \mathrm{~kg} / \mathrm{ha}$ of chemical fertilizer. 
Regardless of the number of weeks, waste that has undergone composting time of at least 5 months has greater plant heights. More mature compost therefore appears to promote better height growth than less mature compost. This is corroborated by the work of [10] which showed that immature compost can induce negative effects on the germination, growth and development of plants.

Generally, the macronutrient contents of composts are much higher than those of the soil. The contribution of composts promotes good plant nutrition, inducing a high growth of plants cultivated under organic amendment compared to plants cultivated on control soil without organic amendment. The poor growth noted for certain plants under compost amendment at the start of growth, particularly at week 3 , could be attributed to salinity or to any toxic elements in the composts [11]. The heights of plants under $\mathrm{N}^{\circ} 3$ compost amendment experienced a growth retardation at the start of the agronomic trials in $\mathrm{M}_{3}$ and $\mathrm{M}_{4}$. This could be explained by the high ion content of the applied compost (Table 5). Indeed, a high cation content can inhibit the absorption of potassium and ammonium [10] which can slow down the growth of the plant. This growth retardation reversed from $\mathrm{M}_{5}$ from which plants subjected to the $\mathrm{N}^{\circ} 3$ compost amendment experienced strong growth compared to that without organic amendment and even those subjected to chemical fertilizer.

These results show, like the germination test, that composts $\mathrm{N}^{\circ} 1$ and $\mathrm{N}^{\circ} 2$ can be considered as ripe at the end of the $3^{\text {rd }}$ month of composting, whereas compost $\mathrm{N}^{\circ} 3$ can only be considered ripe. These results also show that compost with high electrical conductivity has an inhibitory effect on the growth of maize plants (Zea mays L., var. IKENE).

\subsubsection{Grain Yield}

Compost treatments improved corn grain yields compared to the control treatment $\left(32.9 \%\right.$ to $41.2 \%$ for compost $\mathrm{N}^{\circ} 1,29.4$ to $31.8 \%$ for compost $\mathrm{N}^{\circ} 2,28,8$ to $40.6 \%$ for compost $\mathrm{N}^{\circ} 3$ ) (Table 8). This is corroborated by the work of [10] who showed that corn plants under compost treatment have yields of $2.29 \pm 0.29 \mathrm{t} / \mathrm{ha}$ on average against $0.97 \mathrm{t} / \mathrm{ha}$ for the treatment without organic amendment. These results can be explained by the contribution of high levels of organic matter, especially nitrogen and phosphorus, to the soil (Table 10). The work of [17] has shown that a high organic matter content in the soil strongly contributes to the absorption of phosphorus, a very important nutrient, which plays an important role in the photosynthesis of plants.

In $\mathrm{M}_{6}$ (Table 10), the grain yields of the different compost treatments are not significantly different (Duncan, $\mathrm{p} \leq 0.05$ ). The strong disparities observed in $\mathrm{M}_{3}$ gradually disappeared throughout the tests to give way to a relative homogenization of the $\mathrm{M}_{6}$ yields.

Throughout the agronomic trials, chemical fertilizer treatment had the highest yield (Table 10). This could be explained by an optimal concentration of essential plant nutrients $(\mathrm{N}, \mathrm{P}, \mathrm{K})$. 
Table 10. Evolution of the grain yield of maize under different treatments from $M_{3}$ to $M_{6}$ (from the third to the sixth month).

\begin{tabular}{|c|c|c|c|c|}
\hline & $\mathbf{M}_{3}$ & $\mathbf{M}_{4}$ & $\mathbf{M}_{5}$ & $\mathbf{M}_{6}$ \\
\hline$C_{1} D_{1}$ & $\begin{array}{c}1.79 \pm 0.20^{\mathrm{a}} \\
(5.9 \%)\end{array}$ & $\begin{array}{c}1.84 \pm 0.05^{\mathrm{a}} \\
(8.9 \%)\end{array}$ & $\begin{array}{c}2.19 \pm 0.20^{\mathrm{a}} \\
(28.8 \%)\end{array}$ & $\begin{array}{c}2.26 \pm 0.15^{\mathrm{a}} \\
\quad(32.9 \%)\end{array}$ \\
\hline$C_{1} D_{2}$ & $\begin{array}{c}1.65 \pm 0.50^{\mathrm{b}} \\
(-2.4 \%)\end{array}$ & $\begin{array}{c}1.68 \pm 0.20^{\mathrm{b}} \\
(-0.06 \%)\end{array}$ & $\begin{array}{c}2.34 \pm 0.35^{\mathrm{a}} \\
\quad(37.6 \%)\end{array}$ & $\begin{array}{c}2.40 \pm 0.30^{\mathrm{a}} \\
\quad(41.2 \%)\end{array}$ \\
\hline $\mathrm{C}_{2} \mathrm{D}_{1}$ & $\begin{array}{c}1.70 \pm 0.20^{\mathrm{ab}} \\
(0.06 \%)\end{array}$ & $\begin{array}{c}1.88 \pm 0.23^{\mathrm{a}} \\
\quad(11.2 \%)\end{array}$ & $\begin{array}{c}1.60 \pm 0.05^{\mathrm{b}} \\
(-5.9 \%)\end{array}$ & $\begin{array}{c}2.24 \pm 0.35^{\mathrm{a}} \\
\quad(31.8 \%)\end{array}$ \\
\hline $\mathrm{C}_{2} \mathrm{D}_{2}$ & $\begin{array}{c}2.04 \pm 0.05^{c} \\
(20.7 \%)\end{array}$ & $\begin{array}{c}1.96 \pm 0.35^{\mathrm{a}} \\
(16.0 \%)\end{array}$ & $\begin{array}{c}2.20 \pm 0.17^{\mathrm{a}} \\
(29.4 \%)\end{array}$ & $\begin{array}{c}2.20 \pm 0.28^{\mathrm{ab}} \\
(29.4 \%)\end{array}$ \\
\hline $\mathrm{C}_{3} \mathrm{D}_{1}$ & $\begin{array}{c}1.97 \pm 0.17^{\mathrm{cd}} \\
(16.6 \%)\end{array}$ & $\begin{array}{c}2.19 \pm 0.10^{c} \\
(28.8 \%)\end{array}$ & $\begin{array}{c}1.54 \pm 0.06^{\mathrm{b}} \\
(-9.4 \%)\end{array}$ & $\begin{array}{c}2.19 \pm 0.23^{\mathrm{ab}} \\
\quad(28.8 \%)\end{array}$ \\
\hline $\mathrm{C}_{3} \mathrm{D}_{2}$ & $\begin{array}{c}1.95 \pm 0.15^{\mathrm{d}} \\
(15.4 \%)\end{array}$ & $\begin{array}{c}2.29 \pm 0.23^{\mathrm{c}} \\
(35.5 \%)\end{array}$ & $\begin{array}{c}2.02 \pm 0.04^{c} \\
(18.8 \%)\end{array}$ & $\begin{array}{c}2.39 \pm 0.28^{\mathrm{a}} \\
(40.6 \%)\end{array}$ \\
\hline $\mathrm{C}_{\mathrm{O}} \mathrm{M}_{0}$ & $\begin{array}{c}1.69 \pm 0.13^{\mathrm{ab}} \\
(0 \%)\end{array}$ & $\begin{array}{c}1.69 \pm 0.13^{\mathrm{b}} \\
(0 \%)\end{array}$ & $\begin{array}{c}1.70 \pm 0.17^{\mathrm{b}} \\
(0 \%)\end{array}$ & $\begin{array}{c}1.70 \pm 0.17^{\mathrm{c}} \\
(0 \%)\end{array}$ \\
\hline $\mathrm{C}_{\mathrm{o}} \mathrm{M}_{1}$ & $\begin{array}{c}2.59 \pm 0.10^{\mathrm{e}} \\
(53.3 \%)\end{array}$ & $\begin{array}{c}2.59 \pm 0.10^{\mathrm{d}} \\
(53.3 \%)\end{array}$ & $\begin{array}{c}2.61 \pm 0.08^{\mathrm{d}} \\
(53.5 \%)\end{array}$ & $\begin{array}{c}2.61 \pm 0.08^{\mathrm{d}} \\
\quad(53.5 \%)\end{array}$ \\
\hline
\end{tabular}

$\mathrm{C}_{1} \mathrm{D}_{1}$ : Compost $\mathrm{N}^{\circ} 1$ to $10 \mathrm{t} / \mathrm{ha} ; \mathrm{C}_{1} \mathrm{D}_{2}$ : Compost $\mathrm{N}^{\circ} 1$ to $5 \mathrm{t} / \mathrm{ha} ; \mathrm{C}_{2} \mathrm{D}_{1}$ : Compost $\mathrm{N}^{\circ} 2$ to $10 \mathrm{t} / \mathrm{ha} ; \mathrm{C}_{2} \mathrm{D}_{2}$ : Compost $\mathrm{N}^{\circ} 2$ to $5 \mathrm{t} / \mathrm{ha} ; \mathrm{C}_{3} \mathrm{D}_{1}$ : Compost $\mathrm{N}^{\circ} 3$ to $10 \mathrm{t} / \mathrm{ha} ; \mathrm{C}_{3} \mathrm{D}_{2}$ : Compost $\mathrm{N}^{\circ} 3$ to $5 \mathrm{t} / \mathrm{ha} ; \mathrm{C}_{\mathrm{O}} \mathrm{M}_{0}$ : No organic growth; $\mathrm{C}_{\mathrm{O}} \mathrm{M}_{1}$ : $200 \mathrm{~kg} / \mathrm{ha}$ of chemical fertilizer; Vertically, the values followed by the same letter are not significantly different (Duncan, $\mathrm{p} \leq 0.05$ ).

It is concluded that after 6 months of composting, the three types of compost applied at 5 and $10 \mathrm{t} / \mathrm{ha}$ improve the grain yield of maize (Zea mays L., var. IKENE) compared to treatment without organic amendment. Regardless of the type of compost and the dose used, plants treated with composts obtained after six months of composting show a uniform yield.

However, the results of the grain yield do not allow a conclusion to be drawn about the maturity period of the different types of compost used.

\subsubsection{Mass of 1000 Grains}

The mass of 1000 grains is a very relevant parameter for the quality of a yield. The more the plant accumulates organic matter in its grains, the higher the mass of 1000 grains is and vice versa (Toundou, 2017). This is shown by the relatively low mass of 1000 grains of plants under chemical fertilizer treatment, $C_{\mathrm{O}} \mathrm{M}_{1}(276$ $\pm 6 \mathrm{~g}$ ) compared to other treatments (Table 11), while this treatment has the highest grain yield.

The plants subjected to the composts obtained after six months of composting have masses of 1000 grains which are significantly little different from each other. These masses are, however, greater than those of plants grown without organic amendment.

These values are higher than those obtained during the work of [18] who noted a maximum mass of 1000 grains between $302 \pm 20 \mathrm{~g}$ and $322 \pm 13 \mathrm{~g}$. 
Table 11. Evolution of the mass of 1000 grains of the plots subjected to the different treatments.

\begin{tabular}{ccccc}
\hline & $\mathrm{M}_{3}$ & $\mathrm{M}_{4}$ & $\mathrm{M}_{5}$ & $\mathrm{M}_{6}$ \\
\hline $\mathrm{C}_{1} \mathrm{D}_{1}$ & $285 \pm 3^{\mathrm{a}}$ & $290 \pm 4^{\mathrm{a}}$ & $298 \pm 6^{\mathrm{a}}$ & $328 \pm \mathbf{8}^{\mathrm{a}}$ \\
& $(-6.6 \%)$ & $(-4.9 \%)$ & $(-2.3 \%)$ & $(7.5 \%)$ \\
$\mathrm{C}_{1} \mathrm{D}_{2}$ & $285 \pm 5^{\mathrm{a}}$ & $288 \pm 4^{\mathrm{a}}$ & $295 \pm 1^{\mathrm{ab}}$ & $338 \pm 2^{\mathrm{a}}$ \\
& $(-6.6 \%)$ & $(-5.6 \%)$ & $(-3.3 \%)$ & $(10.8 \%)$ \\
$\mathrm{C}_{2} \mathrm{D}_{1}$ & $252 \pm 2^{\mathrm{b}}$ & $266 \pm 6^{\mathrm{b}}$ & $334 \pm 10^{\mathrm{d}}$ & $327 \pm 6^{\mathrm{a}}$ \\
& $(-17.4 \%)$ & $(-12.8 \%)$ & $(9.5 \%)$ & $(7.2 \%)$ \\
$\mathrm{C}_{2} \mathrm{D}_{2}$ & $261 \pm 1^{\mathrm{bc}}$ & $298 \pm 3^{\mathrm{a}}$ & $309 \pm 2^{\mathrm{a}}$ & $338 \pm 3^{\mathrm{a}}$ \\
& $(-14.4 \%)$ & $(-2.3 \%)$ & $(1.3 \%)$ & $(10.8 \%)$ \\
$\mathrm{C}_{3} \mathrm{D}_{1}$ & $311 \pm 0^{\mathrm{d}}$ & $275 \pm 4^{\mathrm{ab}}$ & $279 \pm 9^{\mathrm{a}}$ & $311 \pm 1^{\mathrm{ab}}$ \\
& $(2.0 \%)$ & $(-9.8 \%)$ & $(-8.5 \%)$ & $(2.0 \%)$ \\
$\mathrm{C}_{3} \mathrm{D}_{2}$ & $301 \pm 1^{\mathrm{ad}}$ & $344 \pm 6^{\mathrm{c}}$ & $304 \pm 0^{\mathrm{ac}}$ & $346 \pm 4^{\mathrm{a}}$ \\
& $(-1.3 \%)$ & $(12.8 \%)$ & $(-0.3 \%)$ & $(13.4 \%)$ \\
$\mathrm{C}_{\mathrm{O}} \mathrm{M}_{0}$ & $305 \pm 2^{\mathrm{a}}$ & $305 \pm 6^{\mathrm{a}}$ & $305 \pm 5^{\mathrm{a}}$ & $305 \pm 2^{\mathrm{ab}}$ \\
& $(0 \%)$ & $(0 \%)$ & $(0 \%)$ & $(0 \%)$ \\
$\mathrm{C}_{\mathrm{O}} \mathrm{M}_{1}$ & $276 \pm 6^{\mathrm{ac}}$ & $276 \pm 6^{\mathrm{abc}}$ & $276 \pm 6^{\mathrm{bc}}$ & $276 \pm 6^{\mathrm{c}}$ \\
& $(-9.5 \%)$ & $(-9.5 \%)$ & $(-9.5 \%)$ & $(-9.5 \%)$ \\
\hline
\end{tabular}

$\mathrm{C}_{1} \mathrm{D}_{1}$ : Compost $\mathrm{N}^{\circ} 1$ to $10 \mathrm{t} / \mathrm{ha} ; \mathrm{C}_{1} \mathrm{D}_{2}$ : Compost $\mathrm{N}^{\circ} 1$ to $5 \mathrm{t} / \mathrm{ha} ; \mathrm{C}_{2} \mathrm{D}_{1}$ : Compost $\mathrm{N}^{\circ} 2$ to $10 \mathrm{t} / \mathrm{ha} ; \mathrm{C}_{2} \mathrm{D}_{2}$ : Compost $\mathrm{N}^{\circ} 2$ to $5 \mathrm{t} / \mathrm{ha} ; \mathrm{C}_{3} \mathrm{D}_{1}$ : Compost $\mathrm{N}^{\circ} 3$ to $10 \mathrm{t} / \mathrm{ha} ; \mathrm{C}_{3} \mathrm{D}_{2}$ : Compost $\mathrm{N}^{\circ} 3$ to $5 \mathrm{t} / \mathrm{ha} ; \mathrm{C}_{\mathrm{O}} \mathrm{M}_{0}$ : No organic growth; $\mathrm{C}_{\mathrm{O}} \mathrm{M}_{1}$ : $200 \mathrm{~kg} / \mathrm{ha}$ of chemical fertilizer; Vertically, the values followed by the same letter are not significantly different (Duncan, $\mathrm{p} \leq$ 0.05).

Whatever the type of compost and the dose used, the plants treated with composts obtained after six months of composting have, like the grain yield, a uniform mass of 1000 grains and much greater than that of the plants under treatment of chemical fertilizer.

Here too, it is difficult to draw a conclusion relating to the maturity period of the different types of compost used.

\section{Conclusion}

The results obtained in this work allow to conclude that the treatment at $5 \mathrm{t} / \mathrm{ha}$ of compost $\mathrm{N}^{\circ} 3$ has the best agronomic parameters compared to other types of compost and to treatment without organic amendment. It is therefore more efficient in improving soil fertility. The evolution of the $\mathrm{C} / \mathrm{N}$ ratio, of the electrical conductivity, the phytotoxicity tests and the growth parameters of the composts also allow to conclude that the composts $\mathrm{N}^{\circ} 1$ and $\mathrm{N}^{\circ} 2$ are ripe from the end of the $3^{\text {rd }}$ month of composting. That compost $\mathrm{N}^{\circ} 3$ can only be considered ripe at the end of the $5^{\text {th }}$ month of composting. To improve soil fertility and thus ensure better agronomic performance of maize (Zea mays L., var. IKENE), composts produced from refuse and fruit waste could be used from the end of the $3^{\text {rd }}$ month of composting then that composts from animal litter could only be used after at least 5 months of composting. The results of this work also show that compost with high electrical conductivity has an inhibitory effect on the growth of corn plants (Zea mays L., var. IKENE). 


\section{Acknowledgements}

Thanks go to the composting platform of the NGO ENPRO and to the various chemistry laboratories which served as a framework for carrying out the various elemental analyzes. It's about:

- the chemistry laboratory of the French high school in Lomé,

- the Laboratory of Waste Management, Treatment and Recovery (Laboratory GTVD) in which this work was carried out,

- Center of Excellence "Sustainable Cities" (CERViDA) of University of Lomé.

\section{Conflicts of Interest}

The authors declare no conflicts of interest regarding the publication of this paper.

\section{References}

[1] Food and Agriculture Organization of the United Nations (2017) The Future of Food and Agriculture-Trends and Challenges. Rome, 180.

[2] Akanza, K.P. and Yao-Kouamé, A. (2011) Organomineral Fertilization of Cassava (Manihot esculenta Crantz) and Diagnosis of Soil Deficiencies. Journal of Applied Biosciences, 46, 3163-3172. http://www.m.elewa.org/JABS/2011/46/6.pdf

[3] Detchinli, K.S., Sogbedji, M.J., Bona, K.A. and Atchoglo, R. (2017) Modeling of the Optimal Economic Doses of Farmyard Manure Grown in Corn (Zea mays L.) on Ferralitic Soils in Togo. Journal de la Recherche Scientifique de P Université de Lomé. https://www.ajol.info/index.php/jrsul/article/view/164084

[4] Koledzi (2011) Valorization of Solid Urban Waste in the Districts of Lomé (Togo): Methodological Approach for a Sustainable Production of Compost. 224.

[5] Compaoré, E., Nanema, L.S., Bonkoungou, S. and Sedogo, M.P. (2010) Quality Assessment of Urban Solid Waste Composts in the City of Bobo-Dioulasso, Burkina Faso for Efficient Use in Agriculture. Journal of Applied Biosciences, 33, 2076-2083.

[6] Konaté, Z., Abobi, H.D.A., Soko, F.D. and Yao-Kouame, A. (2018) Effects of Soil Fertilization Using Solid Household Waste Composted in Landfills on the Yield and Chemical Quality of Lettuce (Lactuca sativa L.). International Journal of Biological and Chemical Sciences, 12, 1611-1625. https://doi.org/10.4314/ijbcs.v12i4.9

[7] Dieng, M., Diedhiou, A.S. and Sambe, F.M. (2019) Valorization by Composting of Fermentable Solid Waste Collected at the Ecole Supérieure Polytechnique of the University Cheikh Anta Diop in Dakar: Study of the Phytotoxic Effect on Maize and Corn Plants. International Journal of Biological and Chemical Sciences, 13, 1693-1704.

[8] Koledzi, K.E., Aziablé, E. and Megnassan, S. (2019) Comparative Study of the Evolution of Mass Balance on the ENPRO Composting Platform in Togo. Journal of Chemical, Biological and Physical Sciences Section D, 9, 127-137. https://doi.org/10.24214/jcbps.D.9.1.12737

[9] Puyuelo, B., Gea, T. and Sanchez, A. (2010) A New Control Strategy for the Composting Process Based on the Oxygen Uptake Rate. Chemical Engineering Journal, 165, 161-169. https://doi.org/10.1016/j.cej.2010.09.011

[10] Toundou, O., Agbogan, A., Simalou, O., Koffi, D.S., Awitzi, T. and Tozo, K. (2017) Impact of Composting on the Rehabilitation of the Limestone Quarry of Sika-Kondji (Togo): Effects on the Attraction of Animals and on the Performance of 
Maize (Zea mays L.). Vertigo Journal, 17.

https://journals.openedition.org/vertigo/18838 https://doi.org/10.4000/vertigo.18838

[11] Tchegueni, S., Kili, A.K., Bodjona, M., Koriko, M., Hafidi, M., Baba, G. and Tchangbedji, G. (2012) Effects of Composts Based on Citrus Waste and Shea Cake on the Availability of Soil Phosphorus: A Study under Conditions Controlled. International Journal of Biological and Chemical Sciences, 6, 1381-1389. https://doi.org/10.4314/ijbcs.v6i3.39

[12] Tchanaté, K.N., Segbeaya, K.N., Koledzi, K.E. and Baba, G. (2017) Evaluation of the Physicochemical and Agronomic Quality of the Composts of Urban Waste of the Towns of Lome and Kara in Togo. European Journal of Scientific Research, 147, 469-474.

[13] Aziable, E., Tchegueni, S., Bodjona, M.B., Degbe, A.K., Zamama, M., Hafidi, M., El Meray, M. and Kili, K.A. (2017) Valorization of Agro-Industrial Waste by Bio-Process Aerobic “Composting”. JMES, 8, 1277-1283.

[14] Bokobana, A., Toundou, O., Kolani, L., Amouzouvi, K.A.A., Koledzi, E., Tozo, K. and Tchangbedji, G. (2017) Treatment of Household Waste by Co-Composting with the Legume Cassia occidentalis L. and Some Local Adjuvants to Improve the Agronomic Quality of Composts. Waste Science and Technology, No. 73.

https://doi.org/10.4267/waste-science-technology.3551

[15] Biekre, A.H.T., Tie, B.T. and Dogbo, D.O. (2018) Physicochemical Characteristics of Composts Made from Farm By-Products from Songon in Ivory Coast. International Journal of Biological and Chemical Sciences, 12, 596-609. https://doi.org/10.4314/ijbcs.v12i1.45

[16] Aylaj, M. and Lhadi, E.K. (2008) Evaluation of the Stability and Maturity of Composts Obtained by Aerobic Biodegradation of a Mixture of Household Waste and Chicken Waste. Waste-French Journal of Industrial Ecology, 50, 26-32.

[17] Rabeharisoa, L. (2004) Management of Phosphate Fertilization of Ferralitic Soils in the Highlands of Madagascar. PhD Thesis in Natural Sciences from the University of Antananarivo, Faculty of Sciences, Department of Biology and Plant Ecology, Antananarivo, 165.

[18] Kolani, L. (2007) Effects of Different Types of Compost Made from Cottonseed Hulls on Maize Grain Yield. Engineering Thesis, Higher School of Agronomy (ESA), University of Lomé, Lomé, 91 p. 